\title{
Family communication in the granting of sexual education for adolescents with mental retardation
}

\author{
Hanny Hafiar \\ Faculty of Communication \\ Padjadjaran University \\ Indonesia \\ Aat Ruchiat Nugraha \\ Faculty of Communication \\ Padjadjaran University \\ Indonesia
}

\author{
Yanti Setianti \\ Faculty of Communication \\ Padjadjaran University \\ Indonesia \\ Trie Damayanti \\ Faculty of Communication \\ Padjadjaran University \\ Indonesia
}

\begin{abstract}
The majority of Indonesian society still considers sex education is taboo, so the discussion about this being a rare topic discussed in the family. This can lead to a lack of understanding of the concept of sexuality in the minds of children, especially adolescents with mentally disabled who began to enter a period of puberty. Therefore, the purpose of this paper is for providing sexual education for adolescents with mentally disabled based on the results of research to the parents of Special School (SLB) students in several cities in West Java. The method used is descriptive qualitative and data collection techniques conducted by interview and observation. The results obtained indicate that the parents have difficulty in conducting sex education, due to the lack of knowledge about the information to be provided and the proper delivery methods, and the limitations of parents in obtaining sources information and communities to share experiences, plus phenomenon of easy access to internet media that has the negative content in general in the community, increasing the problems faced by parents in providing sexual education to adolescents with mentally disabled.
\end{abstract}

Keywords-component; family communication; sexual education; adolescents; disability; mentally disabled

\section{INTRODUCTION}

Every child will be metamorphosed then turned into a teenager. There is no exception for children who have mental retardation condition. Mental retardation, defined as individuals with the condition retardation or mental retardation that have a level of intelligence under normal average with a score of IQ lower than 70 [1]. With this condition, children are identified as having a level of intelligence that is below normal, requiring special assistance or services, especially within educational and guidance program [2].

Herein lies the important role of family and community in helping mentally disabled children when entering a period of development into adolescence. Like most teenagers, children with mental retardation who began entering puberty period will also experience physical and psychological changes. The physical changes are most easily identified is the development of reproductive organs.
In normal conditions, every child who is experiencing change going on inside him will feel confusion. If a child is growing up in a family which has open communication, then the child has the chance to get explanations from parents around the confusion will become increasingly wide. Nevertheless, an open family communication will not be too helpful while the child is not able to explicate meaning, due to the mental disabilities, such as mental retardation adolescents.

The giving of information about sexuality and sexual education for adolescents is an important thing to do. Given that more sexual abuse is motivated by ignorance causing not aware of the need for anticipatory action. Moreover, there is a tendency in the society which states that families, caregivers, institutions, or even professional health services often ignoring the needs of women with disabilities because of the emergence of perception that they are not sexually active and does not require sexual health information [3].

Even if there is an awareness of the importance of sexual education for adolescents with mental retardation, but families of young adults with disabilities tend to have difficulties. In addition to the lack of children's ability to understand, is also a lack of knowledge of parents to provide guidance, as well as technological advances that affect the teen environment which can be bad. However, the family still has an obligation to accompany this transitional period, so teenagers do not go wrong in addressing the physical and psychological changes they are experiencing.

There is a statement of Sedyaningrum who wrote that slow learner teenagers at puberty have a tendency not to be able to control his sexual desire. It is influenced by the character of those who always thought short, but it has the same desire with a normal teen [4]. This is the one that becomes the main difficulties faced by families and teachers in providing information on sexual education to the adolescent with mental retardation. However, adolescents with disabilities still need to have preparation related needs to live in the real world after their formal education [5]. This is due to, one's willingness to meet the future requires readiness in health aspects. One's health is not only measured by its physical, mental, and social 
completeness but also through its productivity in activities, as well as in work and livelihood [6] [7].

The importance of providing information about sexual education for young people with mental retardation is triggered by the results of a study that says that more than half of young people with disabilities perform dating activities [8]. As for the other studies mentioned, children with mental retardation have an obsessive attitude in relation to the opposite sex that tends to negative behavior such as free sexual behavior [9] Therefore, the proper education to control sexual development for children with mental retardation during puberty become increasingly needed to prevent adolescent with mental retardation in experiencing sexual abuse. But the problem then is what practical steps are used to provide sexual education to the adolescent with mentally disabled by the parents?

Referring to the problem, it is necessary to do a study related to the complexity of the problems faced by the families; especially the parents of the mentally disabled adolescents in the conduct of sexual education to their children then formulated the theoretical and practical steps that can be done to unravel the problem.

\section{METHOD}

This research uses the descriptive method, to describe the sexual education communication activities within the family. The things that attempt to be identified and described in the explanation are the main communicator in conveying the message, message material delivered, and messaging techniques. The data collected are qualitative and obtained by interview and observation techniques, and FGD. As for interviews used interview guidelines which are semi-open proposed by the interviewer and field enumerator to parents of male adolescents with mental retardation.

The selection of respondents is performed by means of purposive that is looking for parents of parents of male adolescents with mental retardation. This is because at the time of pre-survey was conducted is known that teachers often experience obstacles when overcoming male students who start entering puberty. Furthermore, the data collected are analyzed and classified by sources categories, messages, and how to/delivery methods of sexual education to adolescents with mental retardation in the family in everyday life.

\section{RESUlt AND DisCUSSION}

Based on data collected from the field is known that most of the role of resource persons in the family which provides information about sexual education for male adolescents with mental retardation is the father. This is due to, the level of difficulty faced by the mother when giving information of sexual education is considered higher. There are uncomfortable factors and a sense of unbalance felt by the mother when sharing information about sexual education. Other than that, psychological and physical strength factors of the mother when dealing with conflicts that occur when a male adolescent with mental retardation is refused to accept the advice, prohibitions, or advice from the mother, considered not to meet the need to address the issue.
This is in line with the results of research that says that in addition to the temperament and irritability of the child which has this limitation, parental constraints are also caused due to confusion from parents and ignorance of parents in providing reproductive health materials. [10]. Therefore, provision of information which deals with sexual education for male adolescents with mental retardation, the majority carried out by the father, or a figure that is considered as a father, when the existence of a biological father cannot be reached due to died, divorced and do not live in the same house, or work in a different city.

As for reproductive health materials given by the family, from the father to male adolescents with mental retardation is as an attempt to avoid sexual violence, among other things: the introduction of the characteristics of the development of his own body (sexual organs undergoing change), the way of introduction and the control condition aroused, information regarding the consequences and impact of the unconscious sexual activities performed by adolescents with mental retardation, things can and cannot do (for example: touching the genital part), as well as the effects that the adolescents with mental retardation should bear if committing sexual abuse.

Meanwhile, other efforts made by the father of the male adolescents with mental retardation in addition to providing information directly, is to provide information to the nearest family on how to handle and what to do to prevent the behavior of his adolescents with mental retardation when showing symptoms of sexual abuse, for example, when the child often touching his genital then he should divert to other things, ask to walk, play the ball and so on.

Another action taken is the supervision of the association between the child and the parties which can allow the occurrence of sexual abuse. For example, when the child becomes the object of the game which grazed sexually by his friends, or when there is environmental behavior deemed suspicious, which can lead to acts of sexual abuse. This is consistent with the statement Avin \& Paramastri, (2011) that parents should teach sex education to children in order to protect their reproductive organs so that no one is used by anyone [11].

Father has an important position in the provision of sexual education for her male adolescents who are in a mentally disabled condition, also try to distancing the child from exposure of porno-media, by way of supervising the use of gadgets that are accessed by the teenage siblings, family and relatives, and the friends his mingle with. This becomes very important, considering that when adolescents with mental retardation who are entering puberty, get exposure to pornomedia, the negative impact is even greater because the adolescents have a fairly weak self-control.

In addition, the supervision of exposure to direct visual, also need to be considered, for example, while at the beach or in the pool and see the bodies of others who differ or open, then the attention of adolescents with mental retardation needs to be redirects, that is guided by her parents, in order to minimize the impact of what he saw. This is necessary 
because adolescents with mental retardation have a low knowledge and negative attitudes toward reproductive health [3], so that proper supervision of the family is required. Often parents also feel uncomfortable when it comes to explaining about sex education to his adolescents with mental retardation. Moreover, in an eastern custom culture, sex education is still considered a taboo thing. Mostly, the parents think that the child will know about sexuality by themselves along with age [12].

In providing sexual education, parents of adolescents with mental retardation, provide full guidance by giving examples, actions or information directly about sexual matters is the way to gain experience in an effort to deal with children who start puberty among parents who also have adolescents with mental retardation.

Therefore, sources of information on reproductive health obtained by the parents to be given back to their children, including personal experience, experience among parents who also have adolescents with mental retardation, discussions with teachers at school, searching and reading of information that is relevant to sexual education for adolescents with mental retardation. As for how to deliver the reproductive health information to adolescents with mental retardation, parents tend to use example method, conditioning, discussions, as well as handling directly at the time when the children have the experience.

The duty of parents to provide sexual education can be helped by sexual education delivered by the teachers in school but unfortunately, not many schools that provide reproductive health communication knowledge, though already a lot of news in the mass media which preaches sexual harassment for mental retardation. Therefore, it's been properly for parents, families, and teachers, as well as the nearby environment of adolescents with mental retardation who experience this sexuality development to be more introspective [13]. Therefore, the development of a model for teacher education is one alternative to provide sexual education materials for adolescents with mental retardation. Thus, teachers need to obtain materials or training about children with special needs [14].

There is a lot of literature that describes the ways of introducing sex education to children. These ways can be adapted to be used as a way of introducing sexuality education to adolescents with mental retardation, which of course requires some adjustments, one of which is as follows [12]: (1) introduce part of the body that other people cannot see and touch, explain the body parts that cannot be seen or touched by others. These parts include lips, chest, buttocks and reproductive organs, (2) teach the concept of sex differences to the children, teach how to use public toilets and also teach children how to dress, (3) embed the shy culture to the children, teach children not to change clothes in public places, (4) limiting children from watching television, (5) keep kids away from gadgets, (6) grow a sense of confidence in the children, teach children to always tell the pleasant or unpleasant things to their parents and teach them not to hide things, and (7) talk about sex with children by engaging discussion, sex education in children can be instilled by inviting children to discuss and answer all questions that the child still does not understand.

\section{CONCLUSION}

There are some efforts made by parents, especially the father in communicating sexual education to the adolescent with mental retardation who entered a period of puberty. Family communication can contain both verbal and nonverbal messages. Among them informed about the reproductive organs and their development, tells about the body parts that should not be seen and held by another person and the reason why, and how to control themselves to clean themselves. The father also seeks to give examples on how to avoid sexual abuse as well as how to clean themselves (junub) according to the appropriate procedures they are adhered to.

Furthermore, parents are also acting to directing, prohibit, and distract his adolescent with mental retardation attention when he is in a situation that can stimulate the occurrence of sexual abuse and replace it with activities that are usually favored by his adolescent with mental retardation who was in a period of puberty, such as playing football, outdoor activities that will drain energy and attention of the children, so their attention can be diverted.

Parents also seek to limit the adverse effects of the media, especially gadgets that can stimulate child sexual hormones. In addition, parents also been active in monitoring and warning the children, family, friends, the new environment, environments that have the potential for sexual abuse.

\section{REFERENCES}

[1] Azis, "Pendidikan Seks bagi Anak Berkebutuhan Khusus [Sex Education for Children with Special Needs],” J. Kependidikan, vol. II, no. 2, pp. 182-204, 2014.

[2] N. Abdullah, "Mengenal anak berkebutuhan khusus [Understanding children with special needs],” Magistra, vol. XXV, no. 86, pp. 1-10, 2013.

[3] 'Adiilah, D. M. Wati, and M. Baroya, Ni, "Gambaran Kebutuhan Pelayanan Kesehatan Reproduksi Bagi Remaja Penyandang Cacat di SMPLB dan SMALB TPA Bintoro Kabupaten Jember [[Description of Reproduction Health Services Requirements for Disabled Teenager at Special Junior High School and Special High School TPA Bintoro, Jember Regency],” Artik. Has. Penelit. Mhs., 2015.

[4] R. Sulistyoningrum, "Hubungan Antara Dukungan Sosial dan Akses Terhadap Informasi dengan Perilaku Sehat Reproduksi Remaja Slow Learner [Relationship between Social Support and Access towards Information with Healthy Behavior of Slow Learner Teenagers],” J. Promosi Kesehat., vol. 1/1, pp. 18-24, 2013.

[5] U. F. Rizky, "Identifikasi Kebutuhan Siswa Penyandang Disabilitas Pasca Sekolah Menengah Atas [Identification of Post-High School Disabled Student Requirements],” Indones. J. Disabil. Stud. ISSN 23552158, vol. 1, no. 1, pp. 52-59, 2014.

[6] Y. Setianti, H. Hafiar, T. Damayanti, and A. Nugraha, "Perancangan Model Komunikasi Kesehatan bagi Remaja Disabilitas Tuna Grahita Untuk Menunjang Pembangunan Sosial Di Pangandaran [Health Communication Model Design for Mentally Disabled Teenager to Support Social Development in Pangandaran]," Proceeding UAJY Comicos 2017, 2017.

[7] [A. Putri, "Pendidikan Komunikasi Kesehatan bagi Tunagrahita [Health Communication Education for the Mentally Disabled],” 2017. 
[8] A. Magfirah, "Peer Counseling Tentang Kesehatan Reproduksi dan Perubahan Sikap Seksual Pranikah pada Remaja Disabilitas di Banda Aceh dan Aceh Besar [Peer Counseling about Health Reproduction and Changing Premarital Sexual Behavior towards Disabled Teenagers in Banda Aceh and Aceh Besar],” J. Kesehat. Ilm. Nasuwakes, vol. 7, no. 2, pp. 175-182, 2014

[9] D. R. Utami, “Identifikasi Perilaku Seksual Bebas pada Remaja Tunagrahita [Identification of Free Sex Behavior on Mentally Disabled Teenager],” Skripsi. STIK 'Aisyiyah Yogyakarta, 2015.

[10] I. Rokhmah and Warsiti, "Identifikasi kebutuhan reproduksi bagi remaja perempuan difabel (tuna grahita) [Identification of reproduction needs for disabled teenage girl (mentally disabled)],” vol. 3, pp. 10-12, 2013.

[11] F. Yoisangadji, “Tingkat Pengetahuan Orang Tua Tentang Pendidikan Seks pada Anak Sekolah di SD Negeri Ngrukeman [Parental Knowledge
Level about Sex Education on School Children of Ngrukeman State Elementary School],” Skripsi. Univ. Muhammadiyah Yogyakarta., 2016

[12] I. Nadliroh, "7 Cara Mengenalkan Pendidikan Seks pada Anak Usia Dini [7 ways to Introduce Sex Education to Early Chilhood],” 2017.

[13] M. A. Amiruddin, “Awas! Kejahatan Seksual Bisa Menimpa Anak Berkebutuhan Khusus [Beware! Sexual Crimes could Fall on Children with Special Needs],” 2016.

[14] J. C. Pratiwi, "Sekolah Inklusif untuk Anak Berkebutuhan Khusus: Tanggapan terhadap Tantangan ke Depannya [Inclusive School for Children with Special Needs: Response to the Future Challenges],” Pros. Semin. Nas. Pendidikan. Univ. Sebel. Maret Surakarta., November, pp. 237-242, 2015 